\title{
THERMAL REGIME OF GEORGE VI ICE SHELF, ANTARCTIC PENINSULA
}

\author{
(Abstract) \\ by \\ J.G. Paren and S. Cooper
}

(British Antarctic Survey, Natural Environment Research Council, High Cross, Madingley Road, Cambridge CB3 OET, England)

\section{ABSTRACT}

New data on the thermal regime of George VI Ice Shelf have been obtained by thermistor chains installed through the use of a hot-water drill. Twenty thermistors are used at each site, spaced close together at sea-level and at the base of the ice shelf, and farther apart elsewhere in the ice shelf and in the sea beneath. Based on earlier observations (Bishop and Walton 1981, fig. 7) that the $10 \mathrm{~m}$ temperature warms from around $-10{ }^{\circ} \mathrm{C}$ in the central melt-lake area of the ice shelf (from $70^{\circ} 45^{\prime}$ to $71^{\circ} 45^{\prime} \mathrm{S}$ ) to around $-2^{\circ} \mathrm{C}$ near the northern ice front $\left(70^{\circ} 00^{\prime} \mathrm{S}\right)$, the thermistor chains were deployed at three sites $\left(70^{\circ} 00^{\prime}\right.$, $70^{\circ} 15^{\prime}$ and $70^{\circ} 30^{\prime} \mathrm{S}$ ) along a presumed flow line.

The observations show that as ice flows towards the northern ice front of George VI Ice Shelf, it becomes more temperate in character. Heat from the sea and from the percolation of melt water at the upper surface progressively warms the ice shelf. At mid-depth (the coldest level in the ice shelf) the recorded temperatures were $-6^{\circ} \mathrm{C}$ off Moore Point $\left(70^{\circ} 30^{\prime} \mathrm{S}\right),-4^{\circ} \mathrm{C}$ off Carse Point $\left(70^{\circ} 15^{\prime} \mathrm{S}\right)$ and, near the northern ice front $\left(70^{\circ} 00^{\prime} \mathrm{S}\right)$, between $-1.6^{\circ}$ and $-1.8^{\circ} \mathrm{C}$ depending on the time of year.

The ice-shelf temperatures near the ice front, warmer in mid-summer than the freezing point of fully saline
\end{abstract}

sea-water, are most unusual. The only explanation of the high, fluctuating temperatures found 1 year after drilling is that the hole through the ice shelf was open, allowing unimpeded water movement. This implies that the ice shelf is also warmed by the percolation of sea-water, whose presence was confirmed by ice-core drilling to below sea-level. Confirmation of the presence of brine below sea-level in the ice shelf comes from geo-electrical investigations. A Schlumberger georesistivity array modelled the ice shelf as a simple two-layer structure, with ordinary glacier overlying highly conductive ice. This is consistent with the fact that no radio echoes have been received from the bottom of George VI Ice Shelf to the north of $70^{\circ} 09^{\prime} \mathrm{S}$.

A detailed analysis of the ice-shelf / ocean-temperature profiles was undertaken. This included an analysis of the fluctuation observed in mid-summer at the warmest site and the subsequent transition to a stable isothermal profile through the submerged part of the ice shelf.

\section{REFERENCE}

Bishop, J.F., and J.L.W. Walton. 1981. Bottom melting under George VI Ice Shelf, Antarctica. J. Glaciol., 27(97), 429-447.

\section{GLACIER FLUCTUATIONS IN THE ANTARCTIC PENINSULA: THE LAST DECADE (Abstract)}

\author{
by
}

\author{
J.G. Paren and N.A. Richardson
}

(British Antarctic Survey, Natural Environment Research Council, High Cross, Madingley Road, Cambridge CB3 OET, England)

\section{ABSTRACT}

Following international recommendations (UNESCO / IASH 1969), the decision was made to determine the surface profile of a number of glaciers in Palmer Land and Alexander Island. By comparison with the ice sheet elsewhere on the continent, the chosen glaciers were small and hence more sensitive to the effect of climate over the last few decades. Six profiles were established between 1972 and 1976 and they were re-levelled in the 1985-86 summer. The profiles are between 0.5 and $4.5 \mathrm{~km}$ long and are terminated, at one end at least, by a bench mark established on rock. The profiles were re-measured close to the calendar date of the original survey so that recent trends would not be masked by the annual cycle of accumulation, densification and ablation. Five of the six profiles show that the ice sheet has thickened in the last $10-15$ years, albeit at a slow rate. Changes in four profiles on Alexander Island within $300 \mathrm{~m}$ of sea-level range from a thickening of $66 \mathrm{~mm} \mathrm{a}^{-1}$ to a thinning of $83 \mathrm{~mm} \mathrm{a}^{-1}$; on average the sites show a thickening of just $6 \mathrm{~mm}$ a year. This is similar to the thickening rate of $5 \mathrm{~mm} \mathrm{a}^{-1}$ which was found for a cold site on the spine of the Antarctic Peninsula at $1600 \mathrm{~m}$ above sea-level. The greatest change was found at an intermediate elevation $(500 \mathrm{~m})$. In a snow-field between two parallel mountain groups in the Batterbee Mountains of Palmer Land, thickening averaged $165 \mathrm{~mm} \mathrm{a}^{-1}$. To put these values into perspective, in the absence of glacier flow and summer melting, the glaciers would thicken by up to about $500 \mathrm{~mm}$ each year as a result of the accumulation of snow. 